\title{
Primary Teacher Education In Malaysia
}

Chin Phoi Ching, Institute of Teacher Education, Malaysia

Chin Peng Yee, Institute of Teacher Education, Malaysia

\begin{abstract}
In Malaysia the training of primary school teachers is solely carried out by teacher training institutes which offer the Bachelor of Teaching with Honors (Primary education) program and was first launched in 2007. This program prepares primary school teachers specializing in various subjects or major and is carried out in 27 teacher training institutes. The main aim of this program is to produce quality primary school teachers in terms of knowledge, skills and professional competencies in their respective subjects and in line with the National Philosophy of Education. After a span of five years, has this Bachelor of Teaching program achieve its learning outcomes outlined? Thus this study intends to evaluate this primary teacher education program by focusing on the achievement of learning outcomes $(L O)$ of this four years program. The sample involved in this study is a group of 106 final year student teachers who have completed their $8^{\text {th }}$ semester of study. A questionnaire was administered to check the extent of the learning outcomes being achieved. This questionnaire was developed based on the eight main learning outcomes of this Bachelor of Teaching program. The question items were written individually by referring to the sub outcomes of each main $L O$. Thus this study's main objectives are to find out to what extent the overall $L O$ was achieved and also to determine the importance of each $L O$. The results would serve as guidelines for the teaching staff to further improve their teaching practices and guidance given to students in the future.
\end{abstract}

Keywords: Primary Teacher Education in Malaysia

\section{INTRODUCTION}

n Malaysia the Ministry of Education (MOE) is constantly undergoing changes to ensure that our education system provides quality learning experiences to equip our children with relevant and current knowledge and skills so that Malaysia can produce human assets to meet the needs of the globalised world. Hence our education system is, in many respects, on par with those of many developed countries and has proven to be capable of developing human capital that are able to compete in the global arena. Apart from the emphasis on developing quality human capital, our education system also simultaneously stress on national unity and patriotism.(Corporate Communication Unit, Ministry of Education (MOE).

It is always a challenge for the MOE to produce human capital that is knowledgeable, competent and globally competitive but at the same time retaining our identity. With that in mind, the MOE has developed The Education Development Master Plan (EDMP) 2006 - 2010 which emphasized six strategic thrusts to be achieved. They are:

\footnotetext{
- To build a Malaysian nation

- To develop human capital

- $\quad$ To make national schools attractive to all races

- To narrow the educational divide

- $\quad$ To raise the prestige and status of the teaching profession, and

- To quantum leap excellence of educational institution.
} 


\section{BACKGROUND OF STUDY}

In order to raise the prestige and status of teaching profession as outlined in the EDMP, teacher training colleges were upgraded to institutes of teacher education so as to produce teachers with Bachelor of Teaching degrees. It was hoped that by 2010 this degree programme would meet the target of having only graduate teachers in secondary schools and 50\% graduate teachers in primary school. Thus in the year 2007 the Bachelor of Teaching program was rolled out based on our own conceptual framework for the teacher education curriculum.

This teacher education curriculum was designed

- $\quad$ To be dynamic, relevant, futuristic, responsive, holistic and integrated.

- $\quad$ To use the humanistic approach so that the focus is on the holistic and wholesome development of teachers (the personhood of teachers)

- $\quad$ To apply theories to build teachers' character so as to face future challenges as an educator

- To be coherent so that there's a close link and continuity between effective learning and clinical experience,

- $\quad$ And to encourage lifelong learning

This teaching curriculum was also drawn up based on the following principles- Outcome based learning; Spiral \& Developmental; Coherent; Practical \& Contextual, and Holistic.

\section{Outcome-Based Learning (OBL)}

OBL is emphasized in this teacher education curriculum so that attention is given towards achieving program learning outcomes and course/subject learning outcomes, and at the same time abiding by the requirements of our Malaysian Qualifications Framework and the Malaysian Teachers Standard (Standard Guru Malaysia, 2009).

\section{Coherent}

Our teacher education curriculum aims to link closely course content with practical/clinical experience

\section{Spiral and Developmental}

Our teacher education curriculum is designed such that students repeat the study of a subject at different grade levels, each time at a higher level of difficulty and greater depth. Learning experiences are planned based on offering students with differing and a variety of experiences, different levels of difficulty and contexts in each course and between courses.

\section{Holistic}

The teacher education curriculum was planned to be integrated and balanced emphasis is given to knowledge, skills, values/disposition acquisition. Equal emphasis is also given to " hard skills" and "soft skills" and adopting the global perspective of education according to UNESCO's four Pillars of Education, Education for all (EFA), Education International Understanding (EIU), and Education for Sustainable Development ( ESD). In order to ensure holistic development, curriculum, co curriculum activities and the Teacher Character Building Course (Bina Insan Guru) are also included in the training of student teachers.

\section{Practical and Contextual}

Student teachers will be given practical/hands-on activities based on real life situations and follows best classroom practices. This teacher education curriculum is designed in tandem with the Primary School Standard Curriculum and the implementation of this curriculum also follows the school academic year. 
Based on this teacher education conceptual framework, the Bachelor of Teaching (Hons) 4 years' program drawn up by the Institute of Education, Ministry of Education is a pre service teaching training program to train primary school teachers for more than 15 primary school subjects. The aim of this program is to produce quality primary school teachers in terms of knowledge acquisition, skills and professional competence in their respective fields and in line with the National Philosophy of Education and the Teacher Education Philosophy.

With this main aim in mind, eight learning outcomes were derived for this program. It is hoped that teacher education institutes in Malaysia will produce primary school teachers who can:

- $\quad$ acquire knowledge and deep understanding of content and pedagogical knowledge, curriculum materials, assessment, management of learning environment and learning resources related to their respective fields

- $\quad$ apply and transfer knowledge and skills to carrying out teaching and learning (practical skills) in their respective fields by taking into consideration the physical, social, cultural, psychological factors of children

- demonstrate social skills and responsibilities. They are expected to internalize and practice noble values, obey and believe in religious teachings so as to preserve peace and harmony in the society..

- $\quad$ learn and enact values, ethics and practices in accordance with the Public Services work ethics and the Malaysian Teachers code of ethics

- $\quad$ communicate effectively, shows leadership and team building skills

- $\quad$ use problem solving, critical thinking and scientific skills in learning their respective fields

- $\quad$ practice self regulation and lifelong learning through self reflection for continuous improvement.

- $\quad$ practice management and entrepreneurship skills in their daily lives

These eight learning outcomes are also found in the different components of the Partnership for $21^{\text {st }}$ Century Skills Framework for $21^{\text {st }}$ Century Learning for example Core subjects and $21^{\text {st }}$ century themes, Life and career skills, Learning and Innovation skills. Thus it is obvious that our Malaysian primary teacher education model indeed emphasized on imparting $21^{\text {st }}$ century skills to the student teachers so that they are able to keep learning and adjusting to a rapidly changing environment.

The Bachelor of Teaching (Honours) program carried out by 27 teacher education institutes consists of four major components requires 33 credits, which involves the core and compulsory subjects ( 23 credits), major subjects (86 credits), and two minor subjects ( 24 credits).

For the academic component students will have to follow lectures, practical work, coursework and end of semester examination. The subjects covered are educational studies, major subjects, minors such as English, Physical Education and compulsory subjects such as Art in Education, Islamic Civilization and Asian Civilization (TITAS), Numerical Literacy, Language Literacy and Ethnic Relations.

The second component is the teaching practice. The teaching practice involves a week of school based experience (SBE) for the first and second year; for the third year onwards students will experience a month of teaching practice in the $5^{\text {th }}$ semester, 2 months of teaching practice in the $6^{\text {th }}$ semester, 3 months of teaching practice in the $7^{\mathrm{h}}$ th semester. Finally for the final semester there is a month of school internship whereby students are required to complete a minimum of 3 projects related to their major subjects.

The third component is the Teacher Character Building course or more commonly known as Bina Insan Guru (BIG). The activities carried out within four days involve the usual camping, jungle trekking, kayaking in the sea, games and communal cooking. In the second semester students have to organize and participate in community service like visiting old folks' home and helping out in orphanages. In the third semester students have to organize and participate in an educational project in the schools. For the fourth semester students are involved in adopting a family in a rural area so that they are able to adapt to the various culture in the community. In the fifth semester students have to organize and participate in seminars and bench mark excellent teachers and schools. Similar activities are carried out in the sixth semester. This component is included in the compulsory subjects. 
The last component is co-curriculum which is compulsory. Students can choose to participate in sports and uniform units. For the first semester students follow a co-curriculum management course. Second semester students participate in games, third and fourth semester uniform bodies; fifth semester athletics is offered and in the sixth semester they have to be involved in societies and clubs. This component is also included in the compulsory subjects' weightage.

\section{OBJECTIVES OF STUDY}

After following the program for four years student teachers are expected to achieve the eight learning outcomes outlined above. Thus the objectives of this study is

- $\quad$ to explore to what extent these program learning outcomes have been achieved

- $\quad$ to rate the importance of these learning outcomes to the student teachers, and

- $\quad$ to determine the strength and weakness of this Bachelor of Teaching curriculum.

Only the first two objectives would be discussed in this paper.

\section{METHODOLOGY}

This study used a questionnaire to explore the program learning outcomes achieved and this questionnaire was built based on the eight main learning outcomes. From each main learning outcomes, the sub learning outcomes were framed into 45 question items and rated using a Likert scale ranging from " $1=$ strongly do not agree" to "4=strongly agree". Thus quantitative data was collected and analyzed using SPSS version 12. A total of 106 semester 8 student teachers were involved in answering the questionnaires on the last day of their final term examination. Data analyzed yield a high internal consistency of 0.96 The questionnaire used also collected demographic information of students in Part A, question items in Part B and Part C collected information regarding the strength and weaknesses of the program. In Part D, students were also asked to give suggestions to improve this program. Data collected for Part C and D would be discussed in another paper.

\section{DATA ANALYSIS AND DISCUSSION}

Table 1: Overall Ranking of Program Learning Outcomes

\begin{tabular}{|l|l|c|c|c|c|c|}
\hline & Program Learning Outcomes & N & Min & Max & Mean & Std Deviation \\
\hline 1 & Ethics, Professionalism \& Humanities & 106 & 2 & 4 & 3.76 & 1.86 \\
\hline 2 & Communication, Leadership \& Team building skills & 106 & 2 & 4 & 3.70 & 1.65 \\
\hline 3 & Social skills \& Responsibilities & 106 & 2 & 4 & 3.69 & 2.22 \\
\hline 4 & Lifelong learning & 106 & 2 & 4 & 3.69 & 1.54 \\
\hline 5 & Practical skills & 106 & 2 & 4 & 3.68 & 1.84 \\
\hline 6 & Scientific method, Critical thinking \& Problem solving skills & 106 & 2 & 4 & 3.66 & 1.72 \\
\hline 7 & Entrepreneurship \& Management skills & 106 & 2 & 4 & 3.65 & 1.74 \\
\hline 8 & Knowledge \& Understanding & 106 & 2 & 4 & 3.62 & 2.06 \\
\hline & Total & 106 & 2 & 4 & 3.68 & 1.58 \\
\hline
\end{tabular}

From Table 1, the total mean is 3.68. Ethics, Professionalism and Humanities rank first with a mean of 3.76 which is higher than the total mean. Highest item mean score for Ethics, Professionalism and Humanity is 3.81 (B22) and lowest item mean score is 3.69 (B24). It shows that most of the student teachers agreed that the Bachelor of Teaching (BOTg) program had prepared them to carry out their responsibilities professionally and ethically. According to Gardner (2010), a person with an ethical mind is able to think of himself abstractly and also in a universalistic manner. This ability involves a recognition of rights and responsibilities attached to his/her role or profession. Thus ethics should be infused into the teaching curriculum and institutions where every child and student are involved.

Under this learning outcome, the students felt that this BOTg program has continuously helped them to improve professionally as a student teacher and as a result of this it has increased their self confidence. With this increased self confidence they can carry out their duties professionally and with proper etiquette. They showed 
commitment towards excellence, accountability, integrity, responsibility and empathy in carrying out their work. However they felt that the BOTg program did not really prepared them to face challenges in the teaching profession (item mean B24=3.69).

Second important learning outcome for the students is Communication, Leadership and Team building skills with a mean of 3.70 Highest item mean score for Communication, Leadership and Team Building is 3.79 (B29) and the lowest item mean score is 3.52 (B26). The students felt that the BOTg program had helped them to learn to cooperate with their peers. The lowest item mean score is for being able to construct and defend their arguments based on educational issues clearly and coherently. This is a good indication that our students are not able to integrate theory into practice when discussing educational issues probably in their coursework assignments and classroom discussions. .

Social Skills and Responsibilities and Lifelong Learning share the same mean of 3.69 which is slightly above the total mean. In terms of Social Skills and Responsibilities, the highest item mean score is 3.80 (B19) and the lowest is 3.52 (B13). This results show that student teachers do not strongly agree that the BOTg program had prepared them to manage their time, emotion and stress efficiently. They probably felt that they did not manage their time and workload efficiently and hence added more stress for them. Perhaps educators and planners should consider seriously paying more attention to help students manage their goals and time efficiently.

On the other hand most of them agreed that their involvement in the Teacher Character Building course in the BOTg program had made them aware of their social responsibility to the community and society. Student teachers felt that the BOTg program had also prepared them well in terms of social skills and responsibilities. From this program they felt that they are able to work and interact effectively with people from different social and cultural backgrounds. This indicates that they can tolerate cultural differences, which is a vital requisite for teachers teaching in a multicultural country like Malaysia. Teachers are expected to respond open-mindedly to different ideas and respect cultural diversities and values in a globalized world. They will have to be flexible so that they are able to consider diverse views and beliefs so as to reach decisions and workable solutions in multicultural environments. In fact teachers should leverage social and cultural differences to create new ideas and increase innovation and quality of work (Partnership for $21^{\text {st }}$ Century skills)

For the Lifelong Learning outcome, the highest item mean score for this learning outcome 3.78 (B37) the student teachers agreed that they can self reflect, accept their own weakness and are willing to make changes. Being able to reflect critically on past experiences in order to inform future progress is important for lifelong learning to be successful. Teachers also need to be able to analyze and reflect on their practice, to assess the effects of their teaching, and to refine and improve their instruction continuously (Darling-Hammond, 2005). The lowest item mean score is 3.58 (B40) which is for practicing the principles of Rukun Negara and the National Philosophy of Education in their daily lives.

Practical Skills learning outcome share the same mean as the total mean which is 3.68 The highest item mean score for Practical Skills is 3.75 (B12) and the lowest is 3.61 (B9). The BOTg program had helped the student teachers in applying knowledge to manage their life as a teacher but they were not so sure of being able to create meaningful learning activities in their field of specialization. This should be emphasized in future training of student teachers by teaching training institutes as meaningful learning is important for students' achievement and performance.

Overall mean scores for Practical Skills rank fourth. The BOTg program had prepared the student teachers well in planning learning experiences by taking into consideration the physical, social and cultural background of children. They were able to integrate teaching and ICT skills effectively and were also able to apply various methods in monitoring and assessing children in their field of specialization.

An interesting finding is that the mean score for applying various methods to monitor and assess children's knowledge and skill $(\mathrm{B} 10=3.68)$ is higher than the mean score for their ability to explain the different types of assessment related to their field of specialization $(\mathrm{B} 4=3.54)$ under the Knowledge and Understanding learning outcome. Thus it can be inferred that they have better practical skills than their theoretical knowledge or they 
possibly couldn't link theory into practice. And this is one important outcome that should be achieved by all students. Again teaching staff should focus on linking theory into practice so that meaningful learning takes place.

The lowest item mean score is for planning meaningful learning activities within their field of specialization. Perhaps supervising teachers or mentors can play a major role in helping student teachers improve in this aspect.

Scientific method, Critical thinking and Problem solving skills; Entrepreneurship and Management skills and Knowledge and Understanding learning outcomes are all below the total mean.

Under the Scientific method, Critical thinking and Problem solving skills, students strongly agreed that the BOTg program had trained them to use inquiry skills and learn cooperatively with others but this BoTg program didn't helped them to synthesize information from various sources in order to get a coherent understanding about theory and practice. Synthesizing information is a higher order thinking skills and students felt lacking in this skill. Murray Gell-Mann, a physics Nobel laureate claimed that in this $21^{\text {st }}$ century, the most valued mind will be the synthesizing mind - the mind that can survey a wide range of sources; decide what is important and worth paying attention to; and then put this information together in ways that make sense to oneself and ultimately, to other persons as well. Those whose syntheses make sense to others will become invaluable teachers, communicators, and leaders (Gardner, 2003). Thus this is another important aspect that should be given emphasis so that student teachers can have complete understanding in what they learn and further nurture this skill in their classroom teaching.

For the Entrepreneurship and Management skills, the students strongly agreed that they were able to communicate and convince effectively certain parties to be involved in making decisions but they were not so sure of their abilities to determine financial and other resources required in implementing a project. In other words they are not so capable in determining the necessary requirements for implementing a project. Failure to make responsible financial choices could adversely affect an individual's quality of life. For example, bad financial choices can have a big impact on the organization and also the individual's esteem. At work, people need to know how they can contribute to a larger organization and thus require an entrepreneurial mindset. By recognizing opportunities, risks, and rewards, students/teachers can enhance their workplace productivity and career options and take changing circumstances in their stride (Kay, 2010). Thus financial and entrepreneurial literacy are new imperatives in the $21^{\text {st }}$ century. Perhaps this should be given some priority in the Teacher Character Building course of this BoTg program.

Finally, Knowledge and Understanding learning outcome was ranked the lowest. Students said they were able to explain learning theories to reinforce their pedagogical content knowledge, explain related and relevant content knowledge, determine various teaching and learning resources and materials, but they found that they couldn't explain the procedure and relevant types of assessment related to their field of specialization. Hence teacher educators especially in the major component should to give more emphasis and try all means to help students who are weak in this assessment component. Assessment is an important part of teaching as it would help teachers to judge their children's understanding and at the same time to judge their own teaching effectiveness (Biggs, 2003). Darling-Hammond (2005) stressed that teachers need to be able to use a variety of means for assessing students' knowledge and for evaluating students' different approaches to learning.

In Darling-Hammond's article, she also discussed a list of teaching knowledge that matters in a $21^{\text {st }}$ century education system like having a deep and flexible understanding of subject matter, developing pedagogical content knowledge and also developing pedagogical learner knowledge. Developing these kinds of knowledge requires a tighter coupling of theory and practice in the context of a broader and deeper base of knowledge about learning, development, and teaching and as Darling-Hammond puts it "the key feature of teacher education for the $21^{\text {st }}$ century"

\section{CONCLUSION}

Before summing up, it has to be mentioned that this study is using the instrument for the first time and may be considered a pilot test of this instrument and even though the internal consistency is high there is still room for 
fine tuning the item questions. The second limitation of this study is that the sample involved is from only one teacher education institute and does not represent the entire 27 institutes. Thus for future study of this BOTg program, this instrument can be extended to all the other teacher education institutes in Malaysia. In addition, the results here can be compared with clients' feedback (feedback from school principals) but this will involve a period of time before the feedback comes in. In schools, beginning teachers may be influenced by other environmental factors like learning on the job and from colleagues and hence the feedback from the principals (clients) may not be accurate..

Thus the learning outcomes in terms of importance to the students are Ethics, Professionalism and Humanities; Communication \& Leadership; Social skills and Responsibilities; Lifelong learning and Practical skills. The mean for these five learning outcomes are above the total mean whereas the other three learning outcomesScience method, Critical thinking \& Problem solving skills; Entrepreneurship and Management skills and Knowledge and Understanding were below the total mean. For future review of the BOTg program and to ensure producing quality teachers, special attention should be given to these three learning outcomes so that more effort is given to help student teachers excel in these three areas. Teacher knowledge, skills and attitudes are important school factors influencing children's achievement. Every child should have the right to be taught by a competent and qualified teacher and every teacher should enjoy the right to high-quality teacher preparation program that is relevant to the present $21^{\text {st }}$ century.

\section{AUTHOR INFORMATION}

Dr Chin Phoi Ching is a senior lecturer attached to Teacher Education Institute - Tuanku Bainun campus. She has more than 25 years experience as a teacher educator specializing in Educational Psychology and Pedagogy. She serves as a panel member in drawing up the Bachelor of Teaching program (Educational Studies) for the Teacher Education Institute Malaysia, Ministry of Education. E-mail: phoi_ching@ yahoo.com (Corresponding author)

Dr Chin Ping Yee is an assistant director at the Center of Academic Development, Teacher Education Institute Malaysia, Ministry of Education since 2008. He also serves as a curriculum panel in designing the Bachelor of Teaching program for Chinese Studies and was previously a Chinese Studies lecturer for 10 years. E-mail: penyee_cn@yahoo.com (Corresponding author)

\section{REFERENCES}

1. Aypay, A. (2009). Teachers' Evaluation of Their Pre-Service Teacher Training. Educational Sciences: Theory \& Practice, 9 (3) Summer, 1113-1123.

2. Bellanca, J. \& Brandt, R. (Eds) 2010. $21^{\text {st }}$ Century skills. Rethinking how students learn. IN : Solution Tree Press

3. Buku Panduan PISMP, Insititut Pendidikan Guru Kementerian Pelajaran Malaysia, 2011.

4. Biggs, J. (2003). Teaching for Quality learning at University. ( $2^{\text {nd }}$ edition). UK: Open University Press.

5. Corporate Communication Unit, Ministry of Education Malaysia (http://www.moe.gov.my/?id=168\&aid=922) Accessed 25 Dec 2011

6. Darling-Hammond, L. (2006). Assessing Teacher Education : The Usefulness of Multiple Measures for Assessing Program Outcomes. Journal of Teacher Education, Vol 57, No. 2, March/April pp120-138.

7. Darling-Hammond, L. (2005). Educating the New Educator: Teacher education and the Future of Democracy. The New Educator, Vol 1, pp1-18.

8. Gardner, H. (2010) Five Minds for the Future. In Bellanca, J \& Barndt, R (Eds), $21^{\text {st }}$ century skills. Rethinking how students learn. IN : Solution Tree Press.

9. Kay, K. (2010). $21^{\text {st }}$ Century skills: Why They Matter, What They Are, and How We Get There. In Bellanca, J \& Barndt, R (Eds), $21^{\text {st }}$ century skills. Rethinking how students learn. IN : Solution Tree Press.

10. Partnership for $21^{\text {st }}$ Century skills. (http://www.p21.org) Accessed 29 December 2011.

11. Standard Guru Malaysia, Ministry of Education Malaysia. (http://www.moe.gov.my/sgm/index.html) Accessed 30 January 2012. 


\section{NOTES}

